\title{
Reaksi Pasar Atas Pengumuman Hasil Pemilihan Kabinet Kerja Jilid II Presiden Indonesia Tahun 2019
}

\author{
I Gede Putra Subawa ${ }^{1}$ \\ Fakultas Ekonomi dan Bisnis \\ Universitas Udayana, Indonesia
}

\author{
Ni Putu Sri Harta Mimba² \\ Fakultas Ekonomi dan Bisnis \\ Universitas Udayana, Indonesia
}

\begin{abstract}
Surel : gedesubawa7@gmail.com
ABSTRAK

Penelitian ini bertujuan untuk mengetahui adanya reaksi pasar atas Pengumuman Hasil Pemilihan Kabinet Kerja Jilid II Presiden Indonesia tahun 2019. Penelitian ini merupakan event study dengan event window selama 7 hari. Penelitian dilakukan pada perusahaan yang terdaftar pada Indeks LQ-45 periode AgustusJanuari Tahun 2020. Populasi penelitian ini adalah 45 perusahaan yang terdaftar dalam indeks LQ-45. Reaksi pasar atas Pengumuman Hasil Pemilihan Kabinet Kerja Jilid II Presiden Indonesia tahun 2019 diukur menggunakan abnormal return. Teknik analisis data yang digunakan yaitu uji one-sample t-test. Hasil pengujian menunjukkan bahwa terdapat reaksi pasar saat Pengumuman Hasil Pemilihan Kabinet Kerja Jilid II Presiden Indonesia tahun 2019.
\end{abstract}

Kata Kunci: Event Study; Pengumuman Kabinet Kerja; Abnormal Return.

\section{Market Reaction to the Announcement of the Results of the 2019 Presidential Work Cabinet Volume II of Indonesia}

\section{ABSTRACT}

This study aims to determine the existence of market reaction to the Announcement of the Election Results of the Cabinet Work Volume II of the President of Indonesia in 2019. This research is an event study with event window for 7 days. The study was conducted on companies listed in the LQ-45 Index for the period August-January 2020. The population of this study were 45 companies listed in the LQ-45 index. The sampling method used is the purposive sampling method. Market reaction to the Announcement of the Election Results of the Cabinet Work Volume II of the President of Indonesia in 2019 was measured using abnormal returns. The data analysis technique used is the onesample $t$-test. The test results show that there was a market reaction when the Announcement of the Results of the Election of Cabinet Work Volume II of the President of Indonesia in 2019.

Keywords: $\quad$ Event Study; Work Cabinet Announcement; Abnormal Return.

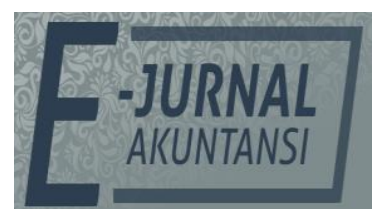

e-ISSN 2302-8556

Vol. 30 No. 11

Denpasar, Nopember 2020

Hal. 2852-2863

DOI:

10.24843/EJA.2020.v30.i11.p11

PENGUTIPAN:

Subawa, I G.P. \& Mimba, N.P.S.H. (2020). Reaksi Pasar Atas Pengumuman Hasil Pemilihan Kabinet Kerja Jilid II Presiden Indonesia Tahun 2019. E-Jurnal Akuntansi, 30(11), 2852-2863

RIWAYAT ARTIKEL: Artikel Masuk:

9 Juli 2020

Artikel Diterima: 19 November 2020

Artikel dapat diakses : https://ojs.unud.ac.id/index.php/Akuntansi/index 


\section{PENDAHULUAN}

Pasar modal memegang peranan yang penting dalam perekonomian suatu negara. Selain menjadi indikator perkembangan ekonomi suatu negara pasar modal juga dapat dijadikan alternatif tempat untuk berinvestasi. Dengan adanya pasar modal, pihak yang memiliki kelebihan dana dapat menginvestasikan dana tersebut dengan harapan memperoleh imbalan (return), sedangkan pihak issuer dapat memanfaatkan dana tersebut untuk kepentingan investasi tanpa harus menunggu tersedianya dana dari operasi perusahaan (Purnama \& Khairunnisa, 2015). Investasi yang efisien adalah investasi yang memberikan risiko tertentu dengan keuntungan yang maksimum atau tingkat keuntungan tertentu dengan risiko minimal. Risiko investasi di pasar modal pada prinsipnya sangat terkait erat dengan terjadinya volatilitas harga saham, dimana naik turunya harga saham ini dipengaruhi kondisi mikro dan makro ekonomi, kebijakan perusahaan, kinerja perusahaan, risiko sistematis, dan efek dari psikologi pasar (Fahmi, 2012:89).

Konsep pasar efisien, menyatakan suatu pasar dikatakan efisien apabila harga saham secara cepat menggambarkan sepenuhnya informasi yang baru dan relevan dimana dapat dilihat dari kecepatan para pelaku pasar dalam merespon semua informasi. Sesuai dengan konsep dasar efisiensi dan kondisi ideal pasar efisien, maka pasar modal yang efisien secara informasional dapat diklasifikasikan menjadi tiga bentuk pasar efisien (Fama et al., 1970), yaitu: efisiensi pasar bentuk lemah (weak form), efisiensi pasar bentuk semikuat (semistrong form), dan efisiensi pasar bentuk kuat (strong form). Pasar efisien dalam bentuk lemah berarti semua informasi di masa lalu akan tercermin dalam harga yang terbentuk saat ini. Pasar efisien dalam bentuk setengah kuat merupakan bentuk efisiensi pasar yang lebih komprehensif karena dalam bentuk ini harga saham tidak hanya dipengaruhi oleh data pasar, tetapi juga dipengaruhi oleh semua informasi yang dipublikasikan.Pasar efisien dalam bentuk kuat yaitu semua informasi baik yang terpublikasi maupun tidak dipublikasikan, sudah tercermin dalam harga sekuritas saat ini.

Menurut Hartono (2015:587) terdapat beberapa informasi dari suatu pengumuman atau peristiwa yang dapat memengaruhi reaksi pasar diantaranya informasi yang dipublikasikan oleh perusahaan emiten seperti pengumuman laba, pengumuman pembagian dividen, pengumuman merger dan akuisisi, pemecahan saham, pengumuman pengembangan produk baru, pengumuman perubahan metode akuntansi, pengumuman pergantian pemimpin perusahaan, dan lain sebagainya.

Informasi yang tidak kalah penting dari peristiwa ekonomi adalah informasi non ekonomi. Walaupun informasi nonekonomi tidak berpengaruh secara langsung dengan pasar modal, informasi ini tetap mampu memengaruhi aktivitas di pasar modal. Informasi nonekonomi diantaranya seperti isu hak asasi manusia, kepedulian terhadap lingkungan sosial, dan peristiwa politik (Permana, 2013).

Peristiwa politik memberikan pengaruh positif atau negatif terhadap penilaian para investor lokal dan calon investor, terutama bagi investor dan calon investor asing, mengingat bahwa pasar modal indonesia didominasi oleh pemodal asing (Lamasigi, 2002). Peristiwa politik merupakan salah satu bagian 
dari lingkungan non ekonomi yang berpengaruh pada kondisi pasar modal. Kondisi politik yang stabil cenderung meningkatkan kinerja ekonomi dalam suatu negara.

Secara tidak langsung peristiwa non ekonomi dapat menjadi pemicu adanya reaksi dari investor. Informasi-informasi yang terkandung di dalam peristiwa tersebut dapat dijadikan sebagai pertimbangan oleh investor dalam melakukan keputusan investasinya. Salah satu faktor non ekonomi yang memberikan dampak di pasar modal suatu negara adalah peristiwa politik (Chien et al., 2014). Peristiwa politik adalah salah satu peristiwa yang dapat menyebabkan fluktuasi harga saham di pasar. Meski suatu peristiwa politik tidak memiliki hubungan langsung atau tidak mengintervensi bursa saham secara langsung, tetapi peristiwa politik dapat menjadi informasi bagi para pelaku pasar saham dan dapat memengaruhi pengambilan keputusan para pelaku pasar sahamhal ini dikarenakan dinamika politik mempunyai kaitan dengan kestabilan ekonomi suatu negara. Menurut Sajid et al., (2014) apabila keadaan ekonomi stabil maka investor akan merasa risiko investasi di pasar modal berkurang. Situasi politik yang stabil memiliki risiko investasi yang rendah dan sistematis untuk mendorong pertumbuhan, investasi modal dan meningkatkan kinerja ekonomi secara keseluruhan.

Kondisi pasar modal memengaruhi kestabilitasan politik yang diikuti dengan kondisi ekonomi, akan membuat para investor merasa aman untuk menginvestasikan dananya di pasar modal. Oleh sebab itu, investor umumnya akan menaruh ekspektasi terhadap setiap peristiwa politik yang terjadi dan ekspektasi mereka akan tercermin pada fluktuasi harga saham ataupun aktivitas volume perdagangan saham di Bursa Efek. Salah satu peristiwa politik yang menarik diuji kandungan informasinya terhadap aktivitas di pasar modal indonesia adalah peristiwa resmi pengumuman menteri Kabinet Indonesia Maju periode 2019-2024. Pengumuman kabinet kerja jilid II Presiden di Indonesia diselenggarakan pada tanggal 23 Oktober 2019, dimana pada tanggal 23 Oktober 2019 Presiden dan Wakil Presiden Joko Widodo-Ma'ruf Amin melantik 34 kabinet kerja di Istana Negara (detik.com, 2019).

Sehubungan dengan informasi pengumuman Kabinet Kerja Presiden Jokowi-Ma'auf Amin. Indeks Harga Saham Gabungan (IHSG) berada dizona hijau meskipun bergerak bervariasi. IHSG sempat menyentuh titik tertinggi yakni 6.228,23 sebelum akhirnya menyentuh titik terendah yakni $6.187,36$ sesi kedua dan ditutup menghijau $6.198,98$ atau naik tipis 0,11 persen. Penguatan IHSG ditopang penguatan pada sektor konsumer yang 0,82 persen dan agrikultur sebesar 0,73 persen.

Pengumuman kabinet kerja jilid II Presiden di Indonesia akan mengakibatkan pasar merespon secara cepat informasi yang membuat bursa saham akan menjadi semakin peka terhadap peristiwa disekitarnya. Diniar dan Kiryanto (2016) menyatakan bahwa makin pentingnya peran bursa saham dalam kegiatan ekonomi membuat bursa saham semakin sensitif terhadap peristiwa disekitarnya, baik berkaitan ataupun tidak berkaitan dengan peristiwa ekonomi.

Reaksi pasar terhadap peristiwa pengumuman hasil pemilihan kabinet kerja presiden jilid II tahun 2019 menggunakan studi peristiwa. Fama et al., (1997) menyatakan bahwa studi peristiwa merupakan studi yang mempelajari 
reaksi pasar terhadap suatu peristiwa (event) yang informasinya dipublikasikan sebagai suatu pengumuman. Para peneliti menggunakan studi peristiwa untuk menganalisa pengaruh dari suatu peristiwa terhadap nilai perusahaan dan untuk mengetahui pengaruh peristiwa terhadap harga saham perusahaan pada saat terjadinya peristiwa.

Beberapa penelitian empiris tentang studi peristiwa non ekonomi telah dilakukan baik di dalam maupun di luar negeri, antara lain dilakukan oleh Khan et al., (2016) yang meneliti dampak pemilihan umum 2013 terhadap harga saham perusahaan publik di Pakistan mendapatkan hasil bahwa Pasar bereaksi positif saat pemilihan umum 2013 di Pakistan. Hal ini sejalan dengan penelitian yang dilakukan Hung (2013) yang meneliti pemilihan Presiden A.S terhadap pasar saham Taiwan menunjukkan bahwa putaran pemilihan Presiden di Amerika Serikat berpengaruh terhadap Taiwanese Stock Market. Dewi et al., (2018) memperoleh hasil bahwa terdapat reaksi positif atas peristiwa pengumuman kebijakan tax amnesty dan reaksi pasar lebih kuat pada perusahaan besar dibandingkan perusahaan kecil. Koulakiotis et al., (2016) meneliti peristiwa pemilu berdasarkan abnormal return dan stock price volatility di Yunani mendapat hasil reaksi pasar saham positif pada hari sebelum tanggal pemilihan dan negatif pada hari pertama pasca pemilihan. Nezerwe (2013) melakukan penelitian di Bursa Saham Mesir menemukan reaksi yang signifikan terhadap abnormal return di EGX30 sebelum dan sesudah pemilu di Mesir. Sedangkan Coulomb \& Sangnier (2014) yang meneliti mengenai reaksi pasar saham dan nilai perusahaan-perusahaan yang mendapat manfaat dari masing-masing kandidat calon Presiden di Prancis, yang mendapati hasil yang siginifikan bahwa ada pengaruh yang signifikan antara abnormal return dengan Pemilihan Presiden Di Prancis.

Penelitian Saraswati \& Mustanda (2018) yang meneliti Reaksi Pasar Modal Indonesia terhadap Peristiwa Pengumuman Hasil Penghitungan Suara Pemilihan Umum Dan Pelantikan Presiden Amerika Serikat juga memperoleh hasil yang serupa yaitu terdapat perbedaan abnormal return sebelum dan setelah peristiwa pengumuman hasil penghitungan suara pemilihan umum Presiden Amerika Serikat, dan terdapat perbedaan abnormal return sebelum dan setelah peristiwa pelantikan Presiden Amerika Serikat. Hasil berbeda didapatkan Sudewa (2015) yang memperoleh hasil bahwa tidak terdapat reaksi pasar dalam pelaksanaan pilpres 2014 hal ini ditunjukkan dengan hasil pengujian statistik terhadap cummulative abnormal return yang menujukkan tidak adanya kandungan informasi sehingga menyebabkan pasar tidak bereaksi. Yuniarthi \& Sujana (2016) memperoleh hasil bahwa tidak terdapat reaksi terhadap peristiwa pencalonan Jokowi menjadi presiden yang diukur dari abnormal return. Suryani (2019) memperoleh hasil bahwa tidak terdapat perbedaan rata-rata abnormal return sebelum dan sesudah Pemilihan Kepala Daerah Serentak tahun 2018. Hal ini terjadi karena peristiwa politik ini tidak terdapat kandungan informasi sehingga pasar tidak bereaksi dilihat dari tidak adanya perbedaan abnormal return dengan kata lain pasar membutuhkan waktu lama dalam pencapaian keseimbangan baru. Penelitian Silaban (2018) meneliti reaksi pasar sebelum dan sesudah kemenangan Donald Trump pada pilpres di Amerika Serikat 2016 yang sebagian besar tidak signifikan yang mengakibatkan secara statistik tidak terdapat 
perbedaan rata-rata abnormal return yang signifikan. Penelitian ini sejalan dengan penelitian Prameswari (2018) menunjukkan bahwa tidak terdapat perbedaan rata-rata abnormal return secara signifikan sebelum dan sesudah Pemilihan Gubernur DKI Jakarta Tahun 2017. Hutami (2015) menguji abnormal return sebelum dan setelah Pilpres Indonesia 9 Juli 2014 mendapat hasil tidak terdapat perbedaan rata-rata abnormal return sebelum dan setelah peristiwa. Purba \& Handayani (2017) yang meneliti reaksi pasar modal pada pilkada DKI Jakarta 2017 putaran kedua mendapatkan hasil menunjukkan bahwa tidak terdapat perbedaan yang signifikan antara Average Abnormal Return (AAR) sebelum dan sesudah peristiwa dan Setiawan \& Mimba (2015) memperoleh hasil bahwa tidak terdapat perbedaan reaksi pasar sebelum dan sesudah pengumuman regulasi loan to value.

Salah satu alat untuk melihat reaksi pasar adalah abnormal return yang diterima investor saat terjadinya peristiwa. Abnormal return adalah selisih antara tingkat keuntungan yang sebenarnya dengan tingkat keuntungan yang di ekspektasikan. Berdasarkan teori pasar efisien, abnormal return yang diterima oleh investor dapat terjadi apabila suatu peristiwa mengandung suatu informasi yang dapat menyebabkan bereaksinya pasar saham dan mempengaruhi pengambilan keputusan investor. Apabila suatu peristiwa tidak mengandung suatu informasi maka pasar tidak akan bereaksi sehingga tidak akan terdapat abnormal return. Uji terhadap kandungan informasi yang terkandung di suatu peristiwa bukan untuk menguji kecepatan reaksi pasar tetapi hanya digunakan untuk melihat ada atau tidaknya reaksi pasar terhadap suatu peristiwa.

Hasil penelitian Prameswari (2018) menunjukkan bahwa tidak terdapat perbedaan rata-rata abnormal return secara signifikan sebelum dan sesudah Pemilihan Gubernur DKI Jakarta Tahun 2017. Coulomb \& Sangnier (2014) yang meneliti mengenai reaksi pasar saham dan nilai perusahaan-perusahaan yang mendapat manfaat dari masing-masing kandidat calon presiden di Perancis, yang mendapati hasil yang siginifikan bahwa ada pengaruh yang signifikan antara abnormal return dengan Pemilihan Presiden di Perancis. Nezerwe (2013) melakukan penelitian di Bursa Saham Mesir menemukan reaksi yang signifikan terhadap abnormal return di EGX30 sebelum dan sesudah pemilu di Mesir. Penelitian Saraswati \& Mustanda (2018) yang meneliti reaksi pasar modal Indonesia terhadap Peristiwa Pengumuman Hasil Penghitungan Suara Pemilihan Umum Dan Pelantikan Presiden Amerika Serikat juga memperoleh hasil yang serupa yaitu terdapat perbedaan abnormal return sebelum dan setelah peristiwa pengumuman hasil penghitungan suara pemilihan umum Presiden Amerika Serikat, dan terdapat perbedaan abnormal return sebelum dan setelah peristiwa pelantikan Presiden Amerika Serikat. Berdasarkan uraian, maka hipotesis yang dirumuskan sebagai berikut.

$\mathrm{H}_{1}$ : Terdapat Reaksi Pasar saat Peristiwa Pengumuman Hasil Pemilihan Kabinet Presiden Indonesia Jilid II Tahun 2019 yang ditunjukkan dengan adanya Abnormal Return yang signifikan di sekitar tanggal pengumuman.

Efisiensi pasar modal ditentukan oleh seberapa besar pengaruh informasi yang relevan, yang dapat dijadikan pertimbangan dalam rangka pengambilan keputusan investasi.Efisiensi pasar modal dapat dijadikan sebagai indikator dalam menentukan kualitas dari suatu pasar modal. Apabila derajat efisiensinya 
semakin tinggi, maka dapat dikatakan bahwa kualitas pasar modal tersebut akan semakin baik. Hartono (2015:585) menjelaskan bahwa suatu pasar dapat disebut pasar efisien jika pasar bereaksi dengan cepat dan akurat untuk mencapai harga keseimbangan yang baru yang sepenuhnya mencerminkan informasi yang tersedia. Konsep pasar efisien ini menyatakan bahwa pemodal selalu memasukkan faktor informasi yang tersedia dalam keputusan mereka sehingga terefleksi pada harga yang mereka transaksikan. Jadi harga yang berlaku di pasar sudah tergantung dari informasi tersebut. Harga saham mengandung tiga faktor yaitu merefleksikan informasi yang bersifat historis, merefleksikan kejadian yang telah diumumkan tetapi belum dilaksanakan, dan merefleksikan prediksi atas informasi yang akan datang.

Pasar efisien yang ditinjau dari sudut informasi saja disebut efisiensi pasar secara informasi (informationally efficient market). Hubungan antara sekuritas dan informasi dapat digunakan dalam mengukur pasar modal efisien. Informasi yang dapat digunakan untuk menilai pasar efisien yaitu informasi yang lama, informasi yang sedang dipublikasikan atau semua informasi termasuk informasi private.

Peristiwa politik merupakan peristiwa non ekonomi yang dapat memengaruhi pengambilan keputusan investor melalui informasi yang terkandung didalamnya. Informasi tersebut dapat memengaruhi pengambilan keputusan para investor dan pada akhirnya pasar bereaksi terhadap informasi tersebut untuk mencapai keseimbangan baru, sehingga dapat dikatakan bahwa peristiwa politik secara tidak langsung mempengaruhi aktivitas di bursa dan informasi-informasi dari peristiwa politik tersebut juga dapat digunakan untuk memetakan ataupun menganalisis risiko-risiko yang mungkin dapat terjadi dimasa yang akan datang (Angelovska, 2011).

Tingkat risiko politik dan pengaruhnya terhadap investasi sangatlah penting untuk diukur sebelum melakukan investasi. Hal ini patut dipertimbangkan karena perubahan kebijakan akan berdampak besar terhadap sektor perekonomian suatu negara. Risiko politik umumnya memiliki keterkaitan dengan pemerintahan serta situasi politik dan keamanan suatu negara. Risiko politik merupakan salah satu factor penting yang mempengaruhi operasi pasar keuangan suatu negara, bias dating dalam berbagai bentuk seperti kudeta, pemilihan, atau perubahan rezim negara (Kabiru, 2015). Diantara semua peristiwa politik, pergantian pemerintahan dengan proses pemilihan umum merupakan peristiwa yang paling memengaruhi pasar (Shaikh, 2019). Ini karena kebijakan-kebijakan yang dibuat oleh pemimpin baru nantinya akan memengaruhi kondisi ekonomi di masa mendatang dan juga secara tidak langsung akan berdampak pada bursa saham tempat terjadinya peristiwa politik tersebut. Jorion \& Goetzmann (1999) menjelaskan bahwa peristiwa politik memberi gangguan di transaksi pasar. Beberapa alasan pentingnya peristiwa politik yang dapat mempengaruhi kesejahteraan ekonomi antara lain untuk menentukan kebijakan jangka panjang, informasi yang langsung diperoleh karena banyak media yang meliput dan harapan para investor bagi calon yang terpilih dapat menguntungkan bagi investor.

Suatu peristiwa yang mengandung informasi akan memberikan abnormal return kepada investor dan sebaliknya peristiwa yang tidak mengandung 
informasi tidak akan memberikan abnormal return kepada investor. Abnormal return adalah selisih antara return sesungguhnya yang terjadi dengan return ekspektasi. Apabila return yang didapatkan lebih besar dari return yang diharapkan disebut selisih return yang positif, sedangkan apabila return yang didapatkan lebih kecil dari return yang diharapkan disebut selisih return negatif.

\section{METODE PENELITIAN}

Penelitian ini menggunakan data sekunder yang didapat dengan mengakses website Bursa Efek Indonesia yaitu www.idx.co.id, www.sahamok.com dan www.finance.yahoo.com. Objek penelitian adalah suatu atribut atau nilai orang atau kegiatan yang mempunyai variasi tertentu yang diterapkan oleh peneliti untuk dipelajari dan kemudian memperoleh kesimpulannya. Adapun objek dalam penelitian ini adalah reaksi pasar terhadap peristiwa pengumuman hasil pemilihan kabinet Presiden Indonesia jilid II tahun 2019.

Sumber data yang digunakan dalam penelitian ini adalah data sekunder yang merupakan data yang diperoleh secara tidak langsung melalui media perantara seperti orang lain dan dokumen. Data sekunder dalam penelitian ini adalah harga penutupan saham harian serta data jumlah saham yang diperdagangkan dan jumlah saham yang beredar masing-masing sekuritas pada saham yang tergolong indeks LQ-45 periode Agustus-Januari 2020 selama 7 hari sebelum dan sesudah Pengumuman Hasil Kabinet Kerja Presiden Indonesia Jilid II yang diperoleh dari website Bursa Efek Indonesia.

Populasi adalah wilayah generalisasi yang terdiri atas obyek atau subyek yang mempunyai kualitas dan karakteristik tertentu yang ditetapkan oleh peneliti untuk dipelajari dan kemudian ditarik kesimpulannya. Populasi yang dimaksud dalam penelitian ini adalah seluruh perusahaan tergolong indeks LQ45 periode Agustus - Januari 2020 yang terdaftar di Bursa Efek Indonesia yang berjumlah 45 perusahaan.

Sampel dalam penelitian ini adalah seluruh perusahaan yang tergolong dalam indeks LQ-45 periode Agustus - Januari 2020 yang terdaftar di Bursa Efek Indonesia. Purposive sampling adalah metode penentuan sampel yang digunakan dalam penelitian ini. Metode purposive sampling adalah metode pengambilan sampel berdasarkan pada kriteria-kriteria tertentu sesuai dengan tujuan penelitian.

Pada penelitian ini menggunakan metode observasi non partisipan yaitu metode pengumpulan data dimana tanpa melibatkan peneliti dalam kegiatan yangdiamati, dan peneliti sebagai pengamat independen. Pengumpulan data yang dilakukan dalam penelitian ini adalah dengan cara mengakses situs Bursa Efek Indonesia melalui www.idx.co.id.

Uji normalitas digunakan untuk menentukan apakah data yang dipergunakan dalam penelitian ini berdistribusi normal atau tidak. Deteksi terhadap normalitas data pada penelitian ini dilakukan dengan uji Kolmogorovsmirnov test. Syarat dari uji normalitas adalah asymp.(2-tailed) $\geq 0,05$, maka dapat dikatakan berdistribusi normal. Dan data dikatakan tidak berdistribusi normal apabila asymp.sig. (2-tailed) $\leq 0,05$.

Alat analisis pada penelitian ini yaitu teknik analisis One sample t-test merupakan salah satu uji parametrik. Syaratnya data berupa kuantitatif dan 
memiliki distribusi normal. Tujuan pengujian dengan one sample t-test adalah untuk memperhatikan apakah ada peristiwa terdapat abnormal return yang siginifikan di sekitar pengumuman Pemilihan Kabinet Kerja Indonesia Maju 2019.

\section{HASIL DAN PEMBAHASAN}

Pasar modal pertama kali dibentuk di Indonesia oleh pemerintahan Belanda pada tanggal 14 Desember 1912 yang diberi nama Verreniging voor de Effectenhandel atau lebih dikenal dengan nama Bursa Efek Jakarta (BEJ) yang berdiri secara resmi di Jakarta. Bursa Efek Jakarta sempat tutup selama periode perang dunia pertama lalu dibuka lagi pada tahun 1925. Selain Bursa Efek Jakarta, pemerintah kolonial juga mengoperasikan bursa parallel di Surabaya dan Semarang (BES). Pada tahun 2007 dengan persetujuan para pemegang saham kedua bursa ,BES dan BEJ digabungkan dan kemudian menjadi Bursa Efek Indonesia (BEI) yang bertujuan meningkatkan peran pasar modal dalam perekonomian Indonesia.

Penelitian ini dilakukan pada saham perusahaan yang terdaftar dalam indeks LQ45 periode bulan Agustus 2019 hingga 2020. Saham - saham LQ45 ini dipilih dengan berbagai alas an diantaranya karena merupakan saham yang aktif diperdagangkan setiap hari bursa, terdiri dari 45 saham dengan kapitalisasi pasar tertinggi dan tingkat likuiditas yang tinggi,serta lolos seleksi denganberbagai kriteria penilaian oleh BEI.

Tabel 1. Uji Statistik Deskriptif CAR

\begin{tabular}{llllll}
\hline & $\mathrm{N}$ & Minimum & Maximum & Mean & Std. Deviation \\
\hline CAR & 45 & $-0,0956$ & 0,0468 & $-0,004823$ & 0,0305523 \\
Valid N (listwise) & 45 & & & & \\
\hline
\end{tabular}

Sumber: Data Penelitian, 2020

Berdasarkan Tabel 1, dapat diamati bahwa cumulative abnormal return terendah (nilai minimum) adalah sebesar - 0,0956 yang dimiliki oleh PT. Erajaya Swasembada Tbk. Cumulative abnormal return tertinggi (nilai maksimum) adalah sebesar 0,0468 dimiliki oleh PT. H.M. Sampoerna. Rata-rata cumulative abnormal return mendekati angka nol, yaitu sebesar -0,004823 dengan standar deviasi sebesar 0,0305523, nilai rata-rata yang lebih kecil dari deviasi standarnya menandakan rentang persebaran data cukup jauh (Ghozali, 2011:21).

Tabel 2. Uji Normalitas CAR

\begin{tabular}{lllllll} 
& \multicolumn{3}{c}{ Kolmogorov-Smirnova } & \multicolumn{3}{l}{ Shapiro-Wilk } \\
\cline { 2 - 7 } & Statistic & df & Sig. & Statistic & Df & Sig. \\
\hline CAR & 0,104 & 45 & $0,200^{*}$ & 0,964 & 45 & 0,177 \\
\hline
\end{tabular}

Sumber: Data Penelitian, 2020

Berdasarkan Tabel 2, dapat diketahui nilai dari signifikansi Cumulative Abnormal Return (CAR) atas Pengumuman Hasil Kabinet Kerja jilid II Presiden Indonesia tahun 2019 sebesar 0,200 > 0,05 yang berarti bahwa data berdistribusi normal, sehingga dapat diteruskan analisisnya ke dalam statistic parametrik yaitu uji one sample t-test. 
Pengujian hipotesis ini menggunakan uji one sample t-test yang diolah dengan software IBM SPSS Statistic 24. Hasil uji hipotesis dapat dilihat dalam Tabel 3 berikut ini.

Tabel 3. Uji One Sample t-test CAR

Test Value $=0$

\begin{tabular}{ccclllll}
\multirow{2}{*}{$\mathrm{T}$} & df & $\begin{array}{l}\text { Sig. } \\
\text { (2-tailed) }\end{array}$ & $\begin{array}{l}\text { Mean } \\
\text { Difference }\end{array}$ & \multicolumn{2}{c}{$\begin{array}{c}\text { 95\% Confidence Interval of } \\
\text { the Difference }\end{array}$} \\
\hline CAR & 8251,960 & 44 & 0,000 & 0,9995322 & 0,999288 & 0,999776 \\
\hline
\end{tabular}

Sumber: Data Penelitian, 2020

Berdasarkan Tabel 3, ,uji one sample t-test diperoleh nilai t 8251,960 dengan nilai probabilitas sebesar $0,000<a(0,05)$, yang berarti bahwa terdapat reaksi pasar atas Pengumuman Hasil Kabinet Kerja jilid II Presiden Indonesia tahun 2019 yang ditunjukan dengan adanya Abnormal Return yang signifikan, yang berarti $\mathrm{H}_{1}$ diterima dan $\mathrm{H}_{0}$ ditolak.

Hasil pengujian hipotesis pertama $\left(\mathrm{H}_{1}\right)$ melalui uji One Sample T-test memperlihatkan bahwa pada tingkat kepercayaan 95\% nilai Sig. (2-tailed) 0,000< 0,05, maka dapat dikatakan bahwa $\mathrm{H}_{1}$ diterima. Hal ini mengartikan bahwa terdapat reaksi pasar pada saat Pengumuman Hasil Kabinet Kerja jilid II Presiden Indonesia tahun 2019 yang ditunjukkan dengan adanya Abnormal Return yang signifikan. Berdasarkan hasil tersebut dapat dikatakan bahwa peristiwa Pengumuman Hasil Kabinet Kerja jilid II Presiden Indonesia tahun 2019 berpengaruh bagi pelaku pasar terhadap kegiatan di pasar modal Indonesia. Informasi yang terkandung dalam peristiwa Pengumuman Hasil Kabinet Kerja jilid II Presiden Indonesia tahun 2019 cukup untuk menggerakkan investor dalam pengambilan keputusan investasinya. Investor dalam melakukan pertimbangan investasi tidak hanya memperhitungkan teknik analisis fundamental seperti melihat kinerja perusahaan, tetapi juga mempertimbangkan peristiwa disekitarnya, seperti peristiwa ekonomi dan non-ekonomi untuk memperoleh return dan terhindar dari risiko kerugian investasi. Hasil penelitian ini didukung oleh penelitian yang dilakukan oleh Saraswati \& Mustanda (2018) yang meneliti reaksi pasar atas peristiwa non ekonomi yaitu peristiwa Pengumuman Hasil Penghitungan Suara Pemilihan Umum dan Pelantikan Presiden Amerika Serikat yang memperoleh hasil bahwa terdapat perbedaan abnormal return sebelum dan setelah peristiwa pengumuman hasil penghitungan suara pemilihan umum Presiden Amerika Serikat, dan terdapat perbedaan abnormal return sebelum dan setelah peristiwa pelantikan Presiden Amerika Serikat. Hasil penelitian ini juga mendukung penelitian yag dilakukan oleh peneliti internasional yaitu penelitian yang dilakukan oleh Nezerwe (2013) yang melakukan penelitian di Bursa Saham Mesir menemukan reaksi yang signifikan terhadap abnormal return di EGX30 sebelum dan sesudah pemilu di Mesir. Coulomb \& Sangnier (2014) yang meneliti mengenai reaksi pasar saham dan nilai perusahaan-perusahaan yang mendapat manfaat dari masing-masing kandidat calon Presiden di Perancis, yang mendapati hasil yang siginifikan bahwa ada pengaruh yang signifikan antara abnormal return dengan Pemilihan Presiden di Perancis. 
Hasil penelitian ini secara teoritis dapat memberikan bukti empiris yang menguatkan konsep kandungan informasi yang mengatakan apabila suatu peristiwa mengandung informasi, maka diharapkan pasar akan bereaksi terhadap peristiwa yang dicerminkan dengan adanya abnormal return. Sebaliknya peristiwa yang tidak memiliki kandungan informasi tidak memberikan abnormal return kepada pasar serta menguatkan konsep efisiensi pasar yang mengatakan pasar bereaksi dengan cepat dan akurat untuk mencapai harga keseimbangan yang baru yang sepenuhnya dicerminkan oleh informasi yang tersedia sehingga dapat memberikan pengaruh pada reaksi pasar modal. Penelitian ini memberikan tambahan informasi secara empiris mengenai bagaimana reaksi pasar terhadap Pengumuman Hasil Kabinet Kerja jilid II Presiden Indonesia tahun 2019 yang ditunjukkan dengan adanya Abnormal Return yang signifikan di sekitar peristiwa.

Hasil penelitian ini secara praktis dapat menjadi pertimbangan bagi investor untuk lebih berhati-hati dengan peristiwa ekonomi maupun non ekonomi. Setiap informasi yang diterima oleh pelaku pasar diharapkan dianalisis terlebih dahulu berdasarkan pertimbangan dan karakteristik masing-masing investor, sehingga pelaku pasar modal dapat mengambil keputusan investasi agar mendapatkan pengembalian yang maksimal. Hasil penelitian ini dapat memberikan gambaran mengenai bagaimana pelaku pasar bertindak pada saat peristiwa non-ekonomi Pengumuman Hasil Kabinet Kerja jilid II Presiden Indonesia tahun 2019.

\section{SIMPULAN}

Berdasarkan hasil pengujian hipotesis 1, terdapat reaksi pasar atas hari Pengumuman Hasil Kabinet Kerja jilid II Presiden Indonesia tahun 2019 yang ditunjukkan dengan adanya Abnormal Return yang signifikan di sekitar tanggal peristiwa. Hal ini terjadi karena Pengumuman Hasil Kabinet Kerja jilid II Presiden Indonesia tahun 2019 terdapat kandungan informasi sehingga pasar membutuhkan waktu cepat dalam pencapaian keseimbangan baru. Investor dalam penelitian ini bereaksi cepat dalam menyerap informasi sehingga sesuai dengan pasar efisien bentuk setengah kuat. Bagi investor, diharapkan penelitian ini dapat menjadi masukan atau pertimbangan sebelum melakukan investasi di pasar modal berdasarkan peristiwa yang terjadi khususnya terkait peristiwa Pengumuman Hasil Kabinet Kerja jilid II Presiden Indonesia tahun 2019. Bagi peneliti selanjutnya diharapkan bisa menggunakan peristiwa ekonomi maupun non ekonomi lainnya untuk menguji kandungan informasi dan menjelaskan reaksi pasar pada peristiwa tersebut.

\section{REFERENSI}

Angelovska, J. (2011). The Impact of Political Events - "Name Issue" on an Emerging Macedonian Stock Market. Journal of Public Administration and Governance, 1(2), 203. https:/ / doi.org/10.5296/jpag.v1i2.926

Chien, W., Mayer, R. W., \& Wang, Z. (2014). Stock Market, Economic Performance, And Presidential Elections. Journal of Business \& Economic Research, 12(2), 159-170. 
Coulomb, R., \& Sangnier, M. (2014). The Impact of Political Majorities on Firm Value: Do Electoral Promises or Friendship Connections Matter? Journal of Public Economics, 115, 158-170. https:// doi.org/10.1016/j.jpubeco.2014.05.001

Dewi, I. G. A. A. P., Wirama, D. G., \& Sari, M. M. R. (2018). Reaksi Pasar Modal atas Kebijakan Tax Amnesty. Jurnal Buletin Studi Ekonomi, 23(2), 61-76.

Diniar, A. H., \& Kiryanto, K. (2016). Analisis Dampak Pemilu Presiden Jokowi Terhadap Return Saham (Studi Kasus Saham LQ-45 di Bursa Efek Indonesia). Jurnal Akuntansi Indonesia, 4(2), 97. https:// doi.org/10.30659/jai.4.2.97-108

Fama, E. F., French, K., Hirshleifer, D., Kothari, S. P., Lamont, O., Mitchell, M., ... Vishny, R. (1997). Not for Quotation: Comments Welcome Market Efficiency, Long-Term Returns, and Behavioral Finance. (June).

Hartono, J. (2015). Teori Portofolio dan Analisis Investasi (Kesembilan). Yogyakarta: BPFE.

Hung, L. C. (2013). U.S. Presidential elections and the taiwanese stock market. Issues and Studies, 49(1), 71-97.

Hutami, R. N. (2015). Abnormal Return Dan Trading Volume Activity Sebelum Dan Setelah Pemilihan Presiden Secara. Jurnal Akuntansi, 4(2), 1-10.

Jorion, P., \& Goetzmann, W. N. (1999). Global Stock Markets in The Twentieth Century. Journal of Finance, 54(3), 953-980. https:// doi.org/10.1111/00221082.00133

Kabiru, J. N., Elly, D., Hellen, O., \& Kinyua, W. (2015). the Effect of General Elections on Stock Returns At the Nairobi Securities Exchange. European Scientific Journal, 11(28), 1857-7881.

Khan, J., Rehman, S. U., \& Hussain, A. (2016). Impact of General Election 2013 on the Share Prices of Public Listed Firms: Evidence from Pakistan. City University Research Journal, 06(01), 101-110.

Koulakiotis, A., Papapanagos, H., \& Papasyriopoulos, N. (2016). Political elections, abnormal returns and stock price volatility: The case of Greece. Investment Management and Financial Innovations, 13(1), 161-169. https:// doi.org/10.21511/imfi.13(1-1).2016.03

Lamasigi, T. A. (2002). Reaksi Pasar Modal Terhadap Peristiwa Pergantian Presiden Republik Indonesia 23 Juli 2001 : Kajian Terhadap Return Saham LQ-45 Di Pt. Bursa Efek Jakarta. Jurnal Dan Prosiding SNA - Simposium Nasional Akuntansi, 5

Nezerwe, Y. (2013). Presidential Elections and Stock Returns in Egypt. Review of Business and Finance Studies, 4(2), 63-68.

Oka Sudewa P., D., \& Ratna Sari, M. (2015). Reaksi Pasar Atas Peristiwa Pilpres 2014. E-Jurnal Akuntansi, 12(3), 465-480.

Permana, H. T., Sutejo, B. S., \& Si, M. (2013). Perbedaan Abnormal Return Pada Sektor Keuangan Sebelum dan Sesudah Peristiwa Pilkada Gubernur Dki Jakarta 20 September 2012. Jurnal Ilmiah Mahasiswa Universitas Surabaya, 2(1), 1-9. https://doi.org/10.1007/springerreference_639

Prameswari, I. A. N. (2018). Analisis Reaksi Pasar Modal Pada Peristiwa Pemilihan Gubernur Dki Jakarta Tahun 2017. E-Jurnal Akuntansi Universitas Udayana, 22(2), 944-975. 
Purba, F., \& Handayani, S. R. (2017). Analisis Perbedaan Reaksi Pasar Modal Indonesia Sebelum Dan Sesudah Peristiwa Non Ekonomi (Studi pada Peristiwa Politik Pilkada DKI Jakarta 2017 Putaran Kedua). Jurnal Administrasi Bisnis (JAB), 51(1), 115-123.

Purnama, Y. S., \& Khairunnisa. (2015). Reaksi Pasar Modal Indonesia Terhadap Pengumuman Hasil Pemilihan Umum Presiden 2009 Dan 2014 Pada Bursa Efek Indonesia Indonesian Capital Market Reaction on the Announcement of the Result of Presidential Election in 2009 and 2014 At Indonesian. EProceeding of Management, 2(1), 246-254.

Sajid Nazir, M., Younus, H., Kaleem, A., \& Anwar, Z. (2014). Impact of Political Events on Stock Market Returns: Empirical Evidence From Pakistan. Journal of Economic and Administrative Sciences, 30(1), 60-78. https:// doi.org/10.1108/jeas-03-2013-0011

Saraswati, N. M. A. W., \& Mustanda, I. K. (2018). Reaksi Pasar Modal Indonesia Terhadap Peristiwa Pengumuman Hasil Penghitungan Suara Pemilihan Umum Dan Pelantikan Presiden Amerika Serikat. E-Jurnal Manajemen Universitas Udayana, 7(6), 2971-2998. https:// doi.org/10.24843/ejmunud.2018.v07.i06.p05

Setiawan, H., \& Mimba, N. (2015). Reaksi Pasar Pada Regulasi Loan To Value. EJurnal Akuntansi, 10(1), 107-120.

Shaikh, I. (2019). The U.S. Presidential Election 2012/2016 and Investors' Sentiment: The Case of CBOE Market Volatility Index. SAGE Open, 9(3), 118. https://doi.org/10.1177/2158244019864175

Silaban, D. P., \& I.B Panji Sedana. (2018). Jurnal Buletin Studi Ekonomi. Vol. 23 No. 1, Februari 2018. Jurnal Buletin Studi Ekonomi, 23(1), 92-107.

Yuniarthi, N., \& Sujana, I. (2016). Reaksi Pasar Modal Terhadap Pencalonan Jokowi Menjadi Presiden Republik Indonesia. E-Jurnal Akuntansi Universitas Udayana, 16(2), 951-977. 